\title{
Nutrient regeneration and oxygen consumption by sediments along an estuarine salinity gradient*
}

\author{
Walter R. Boynton ${ }^{1} \&$ W. Michael Kemp ${ }^{2}$ \\ ${ }^{1}$ Chesapeake Biological Laboratory, P.O. Box 38, Solomons, Maryland 20688, USA \\ ${ }^{2}$ Horn Point Environmental Laboratories, P.O. Box 775, Cambridge, Maryland 21613, USA
}

\begin{abstract}
Nutrient fluxes and oxygen consumption (SOD) across the sediment-water interface were measured in situ along with vertical profiles of dissolved and particulate-phase nutrients in sediments and overlying water at 8 locations along the salinity gradient of Chesapeake Bay during spring and summer. Strong spatial and temporal patterns were evident. Highest rates of sediment $\mathrm{NH}_{4}^{+}$regeneration and SOD occurred in summer at mid-salinity (12 to $17 \%$ ) stations. Sediment fluxes of dissolved inorganic phosphorous (DIP) were always low, possibly due to relatively oxidized conditions in surficial sediments. Nitrate $\left(\mathrm{NO}_{3}^{-}\right)$fluxes generally were directed into the sediments in spring and from the sediments during summer, and in both seasons fluxes were proportional to $\mathrm{NO}_{\overline{3}}$ concentrations in overlying waters. Seasonal shifts in sediment $O: N$ flux ratios suggest that denitrification may have been important in spring but not summer. Significant relations were inferred between C:N:P composition of suspended materials and surficial sediments and the magnitude and direction of sediment-water fluxes. Although accretion of particulate nitrogen in sediments was less than $6 \%$ of $\mathrm{NH}_{4}^{+}$regeneration in the lower bay, it was similar to rates of $\mathrm{NH}_{4}^{+}$flux in the low salinity region, suggesting that burial represents a significant sink for $\mathrm{N}$ in some estuarine zones. SOD constituted an important term in water column $\mathrm{O}_{2}$ budgets at all stations (16-50\% of total respiration), and sediment regeneration of $\mathrm{NH}_{4}^{+}$was capable of supplying 13 to $40 \%$ of calculated phytoplankton $N$ requirement, being more important during the summer period of higher productivity.
\end{abstract}

\section{INTRODUCTION}

Along the salinity gradient of estuaries there are, typically, regular patterns in water column characteristics such as turbidity, nutrients, chlorophyll, and productivity (Sharp et al. 1982, D'Elia et al. 1983). Distinct changes in sediment pore-water constituents and associated diagenic processes have been documented also along the salinity transitions for a few estuaries (Martens \& Goldhaber 1978). Relations between net fluxes of nutrients and other dissolved substances at the sediment surface and pore-water concentrations have been investigated for individual sites in a given estuary (Elderfield et al. 1981, Klump \& Martens 1981), and Callender \& Hammond (1982) examined such relations along the length of the Potomac River estuary. However, interaction between water column and sediment properties in relation to exchanges across the

\footnotetext{
- Contribution No. 1596, University of Maryland Center for Environmental and Estuarine Studies, USA
}

sediment-water interface have not been considered in previous studies over an entire estuarine gradient.

We present here net sediment-water exchanges of dissolved nutrients, and vertical profiles of dissolved and particulate nutrients in sediments and overlying water for a series of stations in Chesapeake Bay from tidal-fresh to near-marine environments. The purpose of the study was to: (1) determine if observed benthic nutrient fluxes could be explained in terms of patterns of sediment and water column properties along the estuarine gradient; (2) place these fluxes in an ecological perspective by considering their importance relative to planktonic processes in the water column.

\section{STUDY AREA}

This study was conducted in Chesapeake Bay (USA), a coastal plain estuary characterized by moderate stratification (Pritchard 1967). The estuary is about 300 $\mathrm{km}$ in length and 8 to $40 \mathrm{~km}$ in width (Fig. 1). Approxi- 


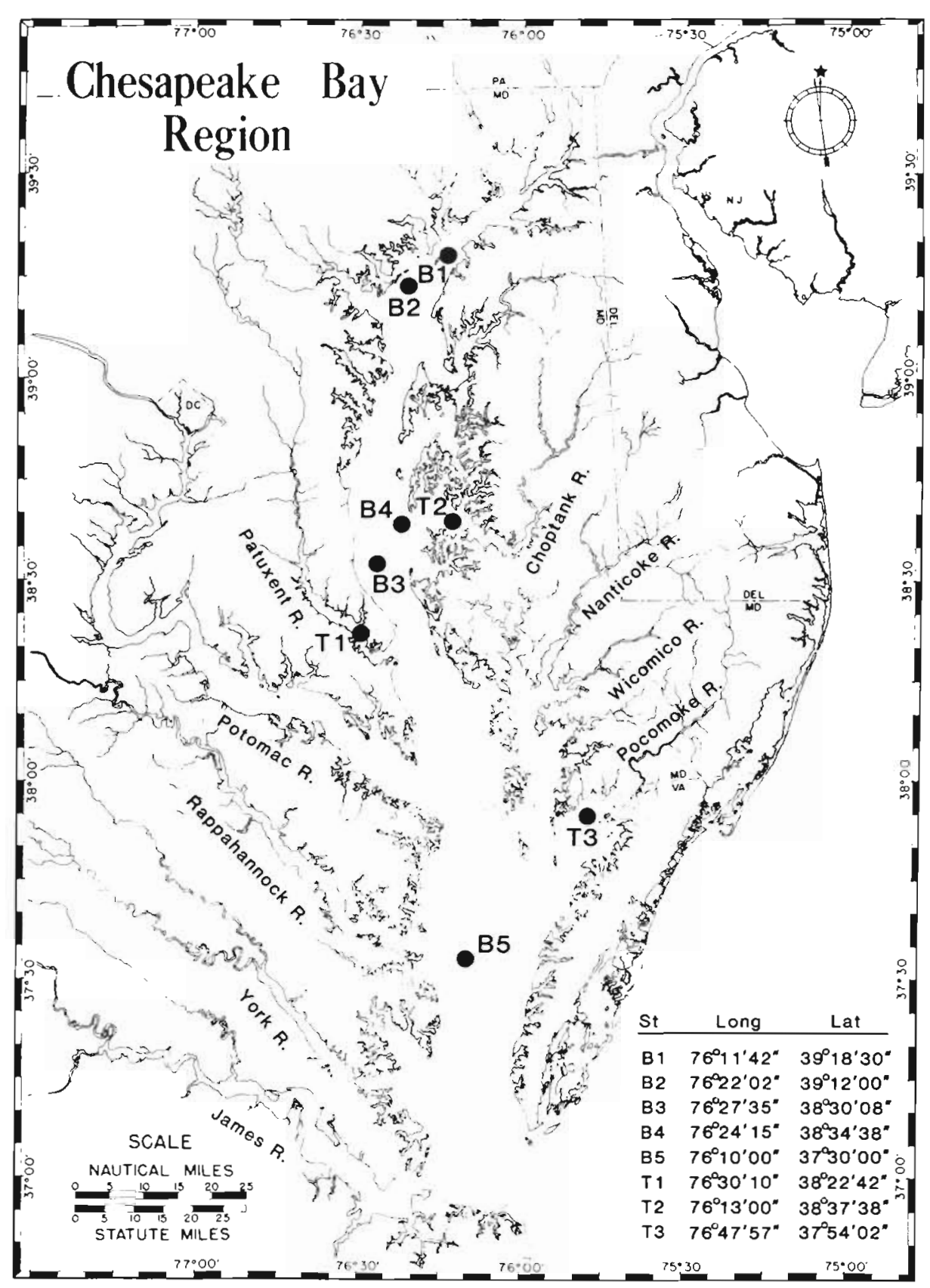

Fig. 1. Station locations in Chesapeake Bay sampled in August 1980 and May 1981

mately $50 \%$ of the bay area is less than $6 \mathrm{~m}$ in depth, while some $35 \%$ is deeper than $9 \mathrm{~m}$ (Pritchard 1952). Our stations were located in 3 contiguous regions positioned along the main axis of the bay including the brackish upper bay ( $\mathrm{km} 0$ to 40 ), the mesohaline midbay area ( $\mathrm{km} 40$ to 190$)$ and the saline lower bay $(\mathrm{km}$ 190 to 300). More detailed descriptions have been previously provided (Whaley et al. 1966, Pritchard 1967, Seitz 1971, Taft et al. 1980). Sampling sites were chosen to be representative of the average depth and sediment type within each zone, and cruise dates (28 July-1 August 1980 and 4-8 May 1981) coincided with periods of peak temperature and freshwater discharge, respectively. Additional stations were established near the mouths of 3 tributaries where mean water depths ( 5 to $7 \mathrm{~m}$ ) were considerably less than in the mid and lower Bay (11 to $14 \mathrm{~m}$ ).

\section{MATERIALS AND METHODS}

In situ chamber measurements. Replicate measurements ( 3 to 4 ) of sediment oxygen demand (SOD) and nutrient flux were made in situ at each station using 
opaque chambers constructed from molded acrylic or welded aluminium. Each chamber was cylindrical in shape with a height of $18 \mathrm{~cm}$ and a circular base of 62 $\mathrm{cm}$ diameter. Chamber volume was $38 \mathrm{l}$, covering a surface area of $0.3 \mathrm{~m}^{2}$. A $10 \mathrm{~cm}$ wide horizontal flange was attached to the edge of the chamber, $6 \mathrm{~cm}$ above the bottom opening, to provide a base for the chamber to rest on the bottom. A submersible pump and oxygen $\left(\mathrm{O}_{2}\right)$ electrode were attached to the inside of each chamber and connected to shipboard by cables. These pumps discharged recirculated water under each chamber through a manifold and were capable of maintaining mean current speeds within the chamber of 10 to $15 \mathrm{~cm} \mathrm{~s}^{-1}$ (at $6 \mathrm{~cm}$ above the sediments), typical of those encountered in near-bottom waters of the study area. A detailed description of the chamber is given in Boynton et al. (1981).

Prior to a measurement, chambers were filled with water to remove all air and slowly lowered downward and were held above $(1 \mathrm{~m})$ the sediment surface for several minutes prior to placement such that nearbottom water was contained within the chamber volume. Placement on the bottom was accomplished with the assistance of SCUBA divers to ensure that the chambers were securely placed and to note penetration into the bottom. Temperature and $\mathrm{O}_{2}$ readings were taken at 10-min intervals over a period of 1 to $3 \mathrm{~h}$. Water samples $(200 \mathrm{ml})$ from within the chambers were obtained 4 to 5 times during each incubation period for analysis of $\mathrm{NO}_{3}^{-}, \mathrm{NH}_{4}^{+}$and DIP; water volume removed was compensated by ambient bottom water entering the chamber via a 1-way valve (Boynton et al. 1981). Nutrient and $\mathrm{O}_{2}$ fluxes were estimated by calculating the mean rate of change in concentration (generally linear) over the incubation period and then converting the volumetric rate to an areal flux using mean height of water inside the chamber. Nutrient and $\mathrm{O}_{2}$ concentration changes for bottom water contained in stirred, $20 \mathrm{l}$ dark bottles incubated at ambient water temperature were used as an estimate of net fluxes in the water overlying sediments, and chamber fluxes were corrected accordingly to obtain net flux across the sediment-water interface.

Sediment profiles and water column characteristics. Vertical profiles of $\mathrm{NH}_{4}^{+}$and DIP in interstitial waters and particulate carbon (PC), nitrogen ( $\mathrm{PN})$ and phosphorus (PP) were also measured for sediments at each station. Sediment cores (65 $\mathrm{cm}$ in depth) were obtained using a gravity corer fitted with a $6.75 \mathrm{~cm}$ diameter plastic liner. After the corer was recovered, the liner was removed and vertically inserted into a glove box which was purged with nitrogen gas. Sediments were hydraulically extruded in $1 \mathrm{~cm}$ intervals and pore water was extracted by pressure filtration (Reeburgh 1967). Pore waters were placed in auto-analyzer vials, capped and immediately frozen. Analysis of particulate fractions was conducted on sub-samples of the solid sediment phase. Sediment bulk densities were also determined at $1-\mathrm{cm}$ (top $10 \mathrm{~cm}$ ) and $5-\mathrm{cm}(11$ to $30 \mathrm{~cm}$ ) intervals. At each station and date water samples were obtained from several depths for $\mathrm{NO}_{3}^{-}, \mathrm{PC}$, PN, PP, and seston. Nutrient samples were processed and frozen for subsequent analysis.

Chemical and physical analyses. $\mathrm{NO}_{3}^{-}, \mathrm{NH}_{4}^{+}$and DIP were measured using the automated method of EPA (1979); total disolved phosphate (TDP, filtered) and total phosphate (TP, unfiltered) analyses used the digestion and neutralization procedure of D'Elia et al. (1977) followed by DIP analysis (EPA 1979); sediment PP concentrations were obtained by acid digestion of dry sediment (Aspila et al. 1976); PC and PN samples were analyzed using a Model 240B Perkin Elmer Elemental Analyzer. Methods of Strickland \& Parsons (1968) were employed for seston determinations. Dissolved oxygen concentrations were measured using an Orbisphere Model $2607 \mathrm{O}_{2}$ electrode and meter which was calibrated daily.

\section{RESULTS AND DISCUSSION}

\section{Sediment nutrient profiles}

Concentrations of PC (Fig. 2) ranged from about 1 to $7 \%$ of dry sediment weight and generally decreased with sediment depth. Surficial $(0$ to $1 \mathrm{~cm}$ ) PC also declined steadily from upper bay to lower bay, being significantly correlated with salinity $\left(r^{2}=0.63\right)$. A notable exception to this vertical trend was observed at the two upper-bay stations where maximum PC values occurred 9 to $15 \mathrm{~cm}$ below the surface. This enrichment in carbon may have resulted from intense deposition of particulate materials in the upper bay during the passage of Tropical Storm Agnes (June 1972), and the depth of this PC maximum is consistent with the event date and deposition rates (Hirschberg \& Schubel 1979). Concentrations of PN ranged between 0.1 and $0.6 \%$ in surface sediments and were considerably reduced in the lower bay (Stations B5, T3). As with PC, values of PN tended to either remain constant or decrease with depth. Particulate phosphorous values ranged between 0.01 and $0.11 \%$ in surface sediments and exhibited longitudinal and vertical patterns similar to those of PC and PN. At St T3 (and to a lesser extent at St B2 and B4), there were considerable differences in PC, PN and PP observed between cruises. Presumably, these differences mainly represent spatial variability rather than seasonal changes in sediment composition (Matisoff et al. 1975).

While there were substantial differences in particu- 

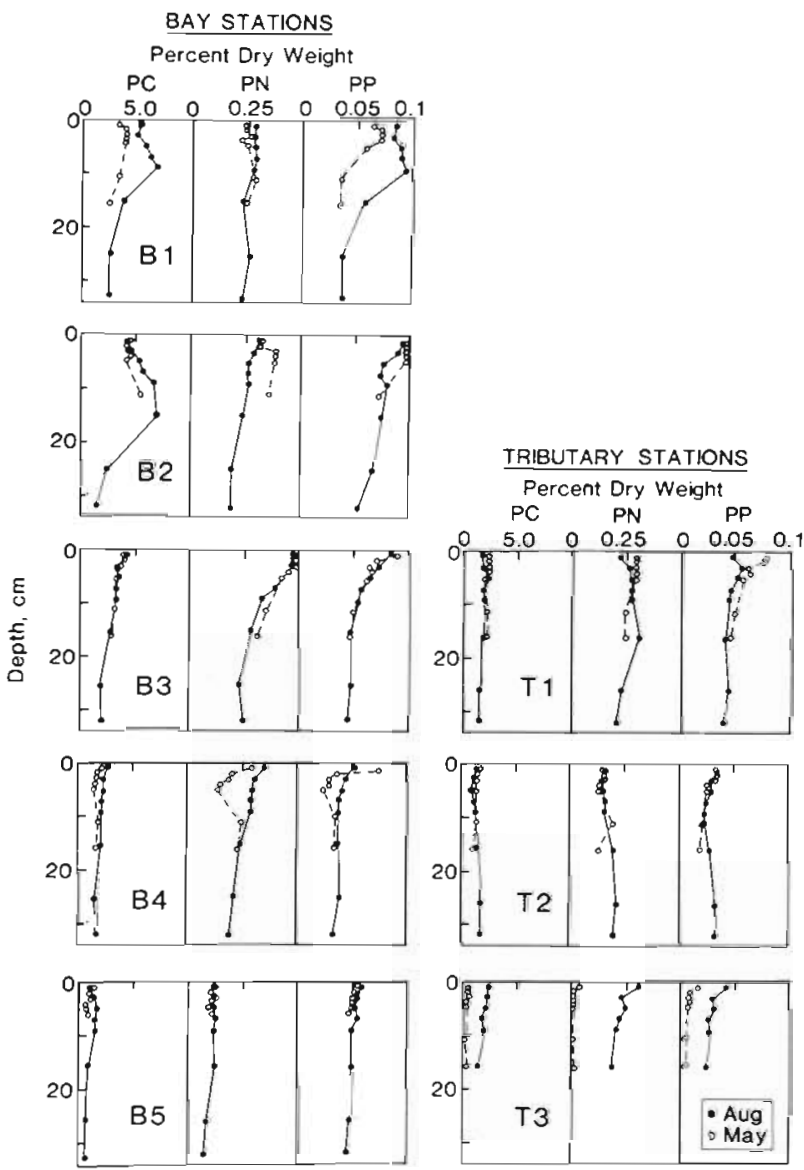

Fig. 2. Vertical distribution of particulate carbon, nitrogen and phosphorus (PC, PN, PP) in sediments at 8 locations in Chesapeake Bay in August 1980 and May 1981

late composition of sediments observed among stations, there was a remarkable consistency in vertical particulate C:N:P ratios at individual stations, except in the upper bay. For example, the C:N:P ratio was $132: 15: 1$ at $1 \mathrm{~cm}$ and $123: 13: 1$ at $30 \mathrm{~cm}$ at St B4. It appears that over a wide spectrum of estuarine conditions and over long time periods, diagenic processes modify PC, PN and PP concentrations in a fashion maintaining nearly constant proportions of these materials.

Pore-water concentrations of $\mathrm{NH}_{4}^{+}$and DIP ranged from about 100 to $1600 \mu \mathrm{M}$ and 1 to $150 \mu \mathrm{M}$, respectively (Fig. 3). With few exceptions, concentrations increased with depth and there was a general pattern of increasing $\mathrm{NH}_{4}^{+}$and DIP concentrations from upper bay to mid-bay stations followed by a sharp decline at the most saline stations. Similar salinity-related patterns of pore-water nutrient concentrations have been reported in other estuaries (Martens \& Goldharber 1978, Callender 1982). The distinctly lower concentrations observed at the high salinity site possibly reflect lower deposition rates of organic material and more
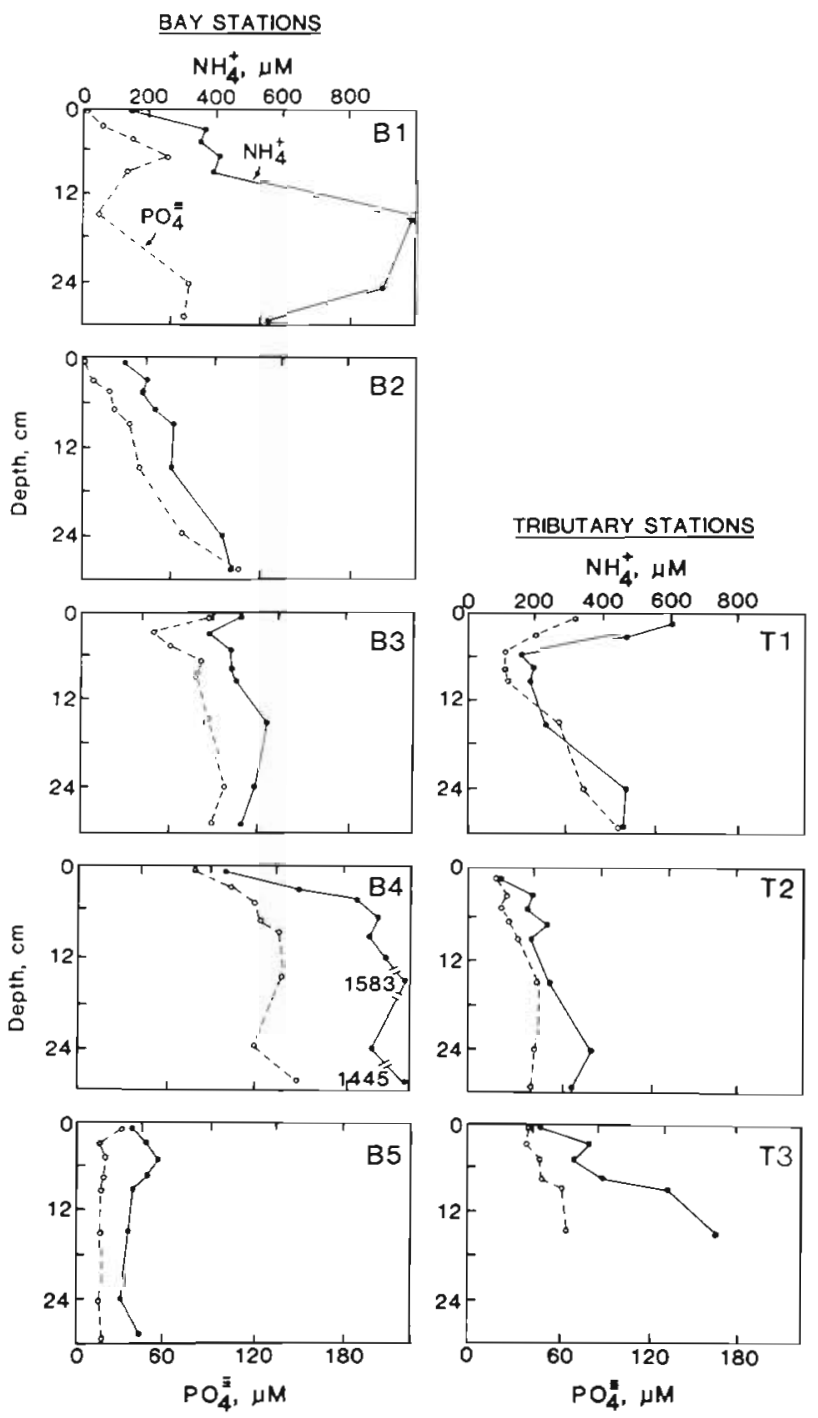

Fig. 3. Vertical distribution of $\mathrm{NH}_{4}^{+}$and dissolved inorganic phosphorus ( $\left.\mathrm{PO}_{4}^{-}\right)$in sediment pore-waters for August 1980 at 8 locations in Chesapeake Bay

complete regeneration of labile planktonic debris near the sediment surface (Martens \& Goldharber 1978). In general, as with sediment particulates, the N:P ratios in pore-waters were constant with depth although some deviations occurred which will be discussed later.

\section{Patterns of fluxes across sediment-water interface}

Rates of SOD (Fig. 4) were quite comparable to those reported for other productive estuarine and coastal environments (Smith 1973, Nixon et al. 1976, Boynton et al. 1980) and to previous measurements made in the vicinity of St B3 (Kemp \& Boynton 1981). There were no significant differences ( 1 -way ANOVA, Student-New- 


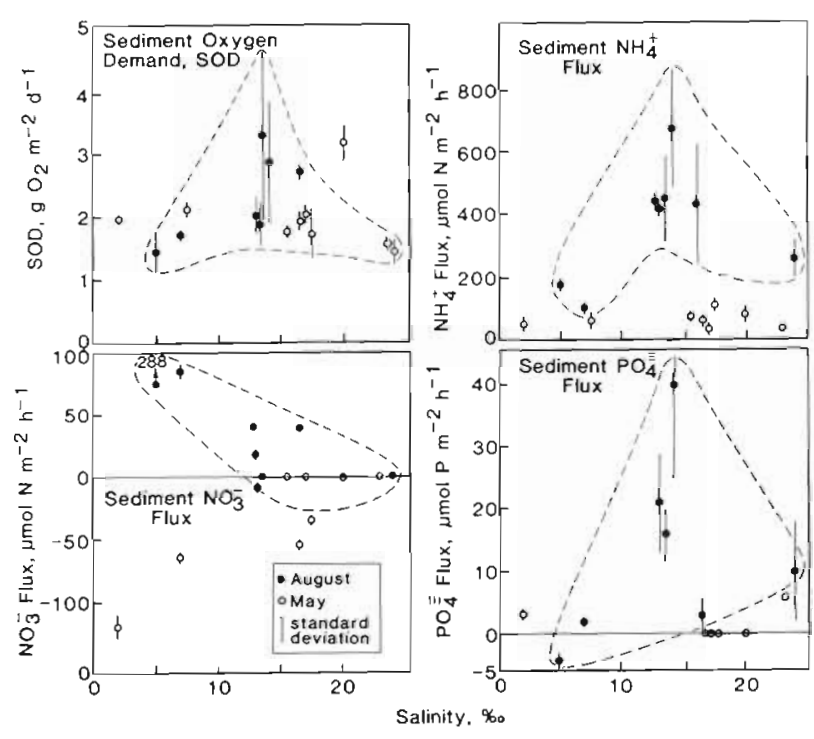

Fig. 4. Average values ( \pm standard deviation) of sediment oxygen demand (SOD), $\mathrm{NH}_{4}^{+}$flux, $\mathrm{NO}_{3}^{-}$flux and $\mathrm{PO}_{4}^{-}$flux in relation to salinity. Envelopes are drawn around selected rates to emphasize spatial patterns. Negative values indicate a net nutrient flux from water to sediments

man-Keuls test; $\mathrm{P}<0.05)$ between rates measured in August and May at the same stations, none among stations in August and only a few significant differences among stations in May [T3 > (B1, B2, B3, B4, T1, T2) > B5].

Ammonium fluxes across the sediment-water interface ranged from 91.3 to $821 \mu \mathrm{mol} \mathrm{N} \mathrm{m}^{-2} \mathrm{~h}^{-1}$ during summer and contrasted sharply with rates observed in May (35.6 to $99.8 \mu \mathrm{mol} \mathrm{N} \mathrm{m}^{-2} \mathrm{~h}^{-1}$ ) which were lower and spatially less variable (Fig. 4). These rates are well within the range of those summarized by Zeitzschel (1980) and Nixon (1981). There were no statistically significant differences among stations in May; however, 2 statistically separate groups were evident in August, with higher values in tributaries and mid-bay areas than in the upper and lower bay.

Nitrate fluxes were directed both into and out from sediments during the study (Fig. 4). During the May cruise fluxes were directed into sediments, decreasing in magnitude in a seaward direction. Nitrate fluxes were inversely correlated with salinity $\left(r^{2}=0.76\right)$ and directly proportional to $\mathrm{NO}_{3}^{-}$concentrations in the overlying water $\left(\mathrm{r}^{2}=0.83\right)$. Spring rates of $\mathrm{NO}_{3}^{-}$uptake were comparable both to those reported previously for the Patuxent estuary (Boynton et al. 1980, 1982) and to direct measurements of sediment denitrification of ${ }^{15} \mathrm{~N}-\mathrm{NO}_{3}^{-}$from overlying water in Japanese coastal sediments during the same season (Koike \& Hattori 1978a, 1978b, Nishio et al. 1982). Significant rates of summer $\mathrm{NO}_{3}^{-}$production occurred only at St B1 and B2, where they were similar with those observed in Narragansett Bay (Nixon et al. 1976).
Sediment fluxes of DIP (Fig. 4) were erratic in late summer, near zero in spring and overall quite low compared to those reported for Chesapeake Bay tributaries (Boynton et al. 1980, Callender 1982) and other estuaries (Nixon 1981). Furthermore, these DIP fluxes were $<10 \%$ of those expected on the basis of observed $\mathrm{NH}_{4}^{+}$regeneration and $\mathrm{N}$ : $\mathrm{P}$ composition of organic matter in surficial sediments (Fig. 4 \& 5). A plausible explanation for these low DIP fluxes would involve the formation of insoluble iron-manganese phosphate complexes and/or sorption to oxyhydroxides, both of which occur under oxic conditions (Bray et al. 1973, Khalid et al. 1978, Krom \& Berner 1980). Klump \& Martens (1981) found that in situ DIP fluxes at Cape Lookout Bight were often less than predicted by pore-water concentration gradients when $\mathrm{O}_{2}$ was present in overlying waters, suggesting that DIP removal occurred at the sediment-water interface. Although sediments were relatively reduced in our August cruise (Eh $<200 \mathrm{~m} \mathrm{~V}$, Jenkins 1981) $\mathrm{O}_{2}$ concentrations in overlying water were $>2 \mathrm{mg} \mathrm{l}^{-1}$ at all stations on both dates. Taft \& Taylor (1976) inferred from $\mathrm{O}_{2}$ and DIP concentrations in the water that release from sediments under anoxic summer conditions was an important source of DIP in the deep waters of Chesapeake Bay. Thus, the absence of anoxic bottom waters during our August sampling may be uncharacteristic of summer conditions in this estuary.

In 2 other studies where spatial distributions of $\mathrm{NH}_{4}^{+}$ and DIP were examined, some trends were also evident. Elderfield et al. (1981) found highest fluxes at a low salinity station in Naragansett Bay (this station also was closest, of the 3 studied, to a sewage outfall). While the data of Callender \& Hammond (1982) suggest no clear pattern for $\mathrm{NH}_{4}^{+}$flux in the Potomac estuary, highest DIP fluxes occurred consistently at salinities similar to those where we found maximum rates.

\section{Relations between sediment composition and nutrient fluxes}

The ratio $C: N$ in coastal and estuarine particulates provides a reasonable index of organic matter source, with ratios of about 6 to 8 typical of plankton detritus (Muller 1977, Smetacek et al. 1978, Walsh et al. 1981). Patterns of $C: N$ in seston and surficial $(0$ to $1 \mathrm{~cm}$ ) sediment $C: N$ along the estuarine salinity gradient of our stations are evident (Fig. $5 \mathrm{a}, \mathrm{b}$ ) where seston $\mathrm{C}: \mathrm{N}$ ratios ranged between 4 and 13 at all stations and both dates. There is some indication of enrichment in seston $\mathrm{N}$ compared to phytoplankton composition in August, particularly in the mid-bay, and the C: $\mathrm{N}$ ratio of seston had significant inverse correlation with $\mathrm{NH}_{4}^{+}$regenera- 

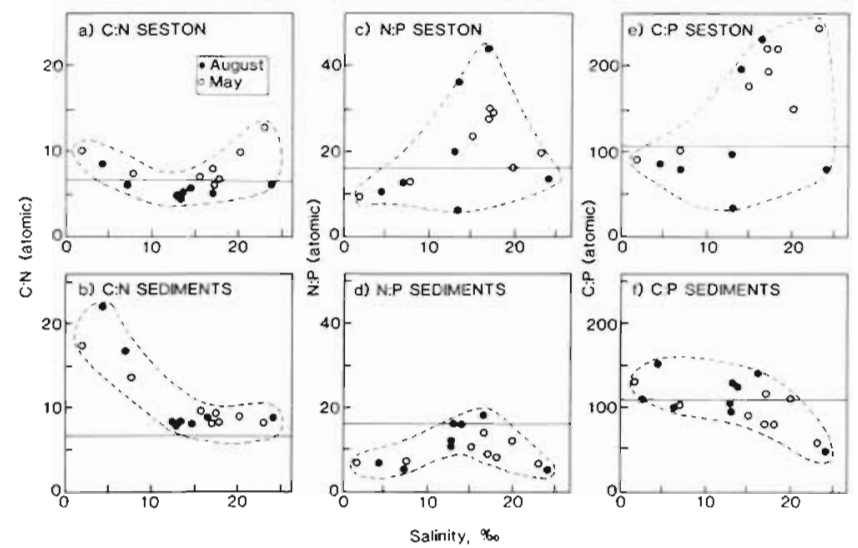

Fig. 5. Composition ratios of particulate material along the salinity gradient in Chesapeake Bay for seston $C: N(a), N: P$ (c), $C: P(e)$ and surficial sediment $(0-1 \mathrm{~cm}) C: N(b), N: P(d)$, $C: P$ (f). Envelopes are drawn around data to emphasize spatial patterns. Horizontal lines indicate expected Redfield composition ratios

tion in the sediments $\left(\mathrm{r}^{2}=0.45\right)$. All measurements of $\mathrm{C}: \mathrm{N}$ in sediments were above 7 , and exceeded 20 in the upper bay, implying a preferential regeneration of $\mathrm{N}$ relative to $\mathrm{C}$, or possibly representing the higher $\mathrm{C}: \mathrm{N}$ ratios typical of terrestrial debris (Müller 1977) in the region closest to the riverine source. This pattern of a more pronounced terrestrial influence in the upper estuary is consistent with that observed by Matson et al. (1983) using $\delta{ }^{13} \mathrm{C}$ for the Neuse and Pamlico estuaries and by Brush \& DeFries (1981) using pollen analysis in the Potomac. At the brackish stations (B1 \& B2) there was also a strong modification of $\mathrm{C}: \mathrm{N}$ from seston to sediment (comparing Fig. 5a and b), with higher $\mathrm{C}: \mathrm{N}$ in sediments and differences averaging about 7 in May and 13 in August. This, again, suggests more rapid benthic recycling of $\mathrm{N}$ compared to $\mathrm{C}$. Similar decreases in $\mathrm{C}: \mathrm{N}$ from seston to sediments have been reported for other coastal environments (Stephens et al. 1967, Hargrave \& Taguchi 1978).

Seston N:P along the length of Chesapeake Bay exhibited a wide range (from 5 to 44 ), with values at or below phytoplankton composition occurring generally in upper and lower bay (Fig. 5c). In the tributaries and mid-bay region where primary production, SOD and $\mathrm{NH}_{4}^{+}$flux were maximal, N:P exceeded 20 for 7 of 8 observations. A significant correlation was found between mean $\mathrm{N}: \mathrm{P}$ in seston and $\mathrm{NH}_{4}^{+}$regeneration in sediments $\left(r^{2}=0.60\right)$. Similarly, sediment values of $\mathrm{N}: \mathrm{P}$ were mostly below phytoplankton composition (Fig. 5d), indicating a relatively slow release of DIP, except in the mid-bay region which is apparently more prone to summer anoxia with rapid release of DIP (Taft \& Taylor 1976).

By comparing $\mathrm{C}: \mathrm{P}$ ratios in particulate matter, further qualitative evidence is obtained regarding organic sources and regeneration rates. Seston C:P exhibited a pattern similar to N:P (Fig. 5e). In the sediments, $C: P$ did not vary greatly from Redfield proportions, but exceeded 130 at St B1, while low C:P $(<100)$ in the lower bay may have resulted from $P$ bound in Fe-Mn oxy-hydroxide complexes in these relatively aerobic sediments (Fig. 5f). Moreover, the radical shift of particulate C:P from seston to sediments in mid and lower estuary implies marked differential diagenesis of P relative to $\mathrm{C}$. Thus, overall, the patterns apparent in the C:N:P composition of suspended and recently deposited particulates were consistent with in situ measurements of $\mathrm{NH}_{4}^{+}, \mathrm{DIP}$, and $\mathrm{O}_{2}$ flux across the sediment-water interface.

\section{Stoichiometric flux ratios', denitrification and burial of nitrogen}

Aerobic decomposition of organic matter, derived from phytoplankton, results in the generation of about 1 atom of $\mathrm{N}$ for every 17.25 oxygen atoms consumed if $\mathrm{N}$ oxidation goes to $\mathrm{NO}_{3}^{-}$; or $1 \mathrm{~N}$ atom per $13.25 \mathrm{O}$ atoms if $\mathrm{NH}_{4}^{+}$is the end product (Redfield 1934, Alvarez-Borrego et al. 1975). Nixon and his colleagues (Nixon et al. 1976, 1980, Nixon 1981) have discussed the possible implications of $\mathrm{O}: \mathrm{N}$ ratios of fluxes across the sediment-water interface. Actual fluxes for Narragansett Bay sediments exhibited considerable departure from stochiometric ratios predicted by the Redfield model, with values of O:N tending to be anamolously high (Nixon et al. 1976, 1980). The proportionately low release of $\mathrm{N}$ (mostly as $\mathrm{NH}_{4}^{+}$) from sediments to overlying water has been attributed to high rates of denitrification for Narragansett Bay (Seitzinger et al. 1980, 1984, Nixon 1981). However, the generality of this pattern is an open question, and some systems seem to follow the Redfield prediction more closely (e.g. Fisher et al. 1982).

In the present study, distinctly different patterns of $\mathrm{O}: \mathrm{N}$ flux ratios were evident between spring and summer cruises (Fig. 6). Mean O:N of benthic fluxes for 8 stations was consistent with the Redfield model in August, being 18.5 with only $\mathrm{NH}_{4}^{+}$regeneration considered and 13.8 including $\mathrm{NO}_{3}^{-}$evolution as well. A significant correlation was obtained here for $\mathrm{O}_{2}$ consumption versus $\mathrm{NH}_{4}^{+}$regeneration $\left(\mathrm{r}^{2}=0.55\right)$. Conversely, the mean $\mathrm{O}: \mathrm{N}$ flux ratios for May measurements were 182 and 95 with and without consideration of $\mathrm{NO}_{3}^{-}$flux. Thus, while $\mathrm{N}$ regeneration in summer was generally consistent with the Redfield model, evidently processes other than simple aerobic decomposition of organic matter were operative in the spring.

Jenkins \& Kemp (1984) have reported strong seasonal trends for the coupled nitrification-denitrifica- 


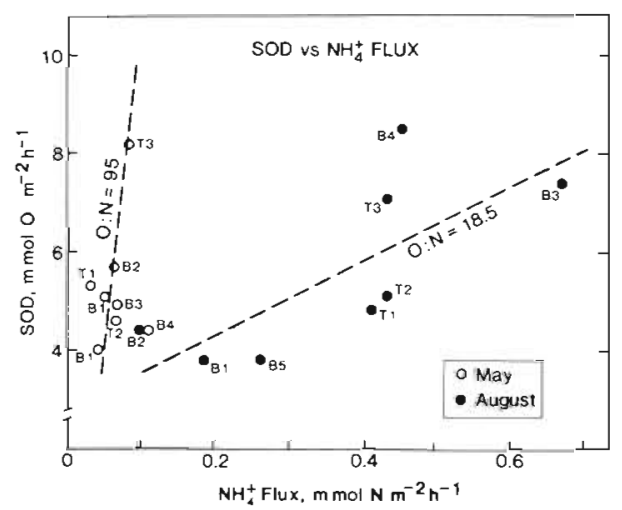

Fig. 6. Relations between sediment $\mathrm{NH}_{4}^{+}$flux and SOD in August (solid circles) and May (open circles) at 8 locations in Chesapeake Bay. Lines through points are drawn by inspection, and mean $\mathrm{O}: \mathrm{N}$ ratios for August and May data are given

tion reaction in a tributary of Chesapeake Bay (Patuxent Estuary). Rates of about 80 to $200 \mu \mathrm{mol} \mathrm{N} \mathrm{m}{ }^{-2} \mathrm{~h}^{-1}$ were measured in April compared to $<1.0 \mu \mathrm{mol} \mathrm{N} \mathrm{m}{ }^{-2}$ $\mathrm{h}^{-1}$ in August. The spring rates are similar to the mean $\mathrm{NH}_{4}^{+}$regeneration rates in the Patuxent during that period (Boynton et al. 1980, 1982), and thus are capable of accounting for a doubling of the $\mathrm{O}: \mathrm{N}$ flux ratio. The strong seasonality of $\mathrm{NO}_{3}^{-}$fluxes across the sedimentwater interface in the upper bay is consistent with this argument that denitrification would explain the anomalous O:N ratios (Fig. 6). In this case, denitrification in May would have been coupled to sediment nitrification throughout the estuary with denitrification of water column $\mathrm{NO}_{3}^{-}$also extant at upper bay stations.
Another possible explanation for the discrepancy between observed stoichiometric ratios for benthic fluxes and phytoplankton elemental proportions would be differential burial of $\mathrm{N}$ relative to $\mathrm{C}$ or $\mathrm{P}$. The rate of $C, N$ or $P$ burial $\left(F_{1}\right)$ can be estimated from the following relation, $F_{i}=C_{1}(\varrho) \omega$, where $C_{i}=\%$ composition of particulate material buried for species $i ; \varrho=$ dry bulk density of solids buried; $\omega=$ rate of sediment accretion. Various estimates of $\omega$ are available for upper and middle Chesapeake Bay (Biggs 1970, Schubel \& Hirschberg 1977, Goldberg et al. 1978, Hirschberg \& Schubel 1979), and values of 9.0 and 1.2 $\mathrm{mm} \mathrm{yr}^{-1}$ are generally representative for St B1 and B4, respectively. Applying these deposition rates to our measurements of $\mathrm{C}_{\mathrm{n}}$ (\% nitrogen $=1.25 \% \mathrm{~N}$ for both stations, Fig. 2) and $\mathrm{Q}\left(0.42\right.$ and $0.46 \mathrm{~g} \mathrm{~cm}^{-3}$ for $\mathrm{B} 1$ and B4, Boynton et al. 1982) at $20 \mathrm{~cm}$ sediment depth, we calculate long-term means of 77 and $11 \mu \mathrm{mol} \mathrm{N} \mathrm{m}{ }^{-2} \mathrm{~h}^{-1}$ for burial of $\mathrm{N}$ at St B1 and B4, respectively.

At the upper bay station this rate is close to the mean of $\mathrm{NH}_{4}^{+}$fluxes measured on the 2 sampling dates, while it is less than $6 \%$ of the mean $\mathrm{NH}_{4}^{+}$regeneration for $\mathrm{St}$ B4 (Table 1). Hence, burial is potentially important in the $\mathrm{N}$ budget of upper bay sediments, while less so for the middle bay. To be a significant source of the anomaly in O:N and N:P flux ratios observed for benthic regeneration of organic matter, sediment particulates must be enriched in $\mathrm{N}$ relative to $\mathrm{C}$ and depleted relative to $P$. In fact, we found no enrichment of $\mathrm{N}$ relative to $\mathrm{C}$ at any of our stations; however, considerable depletion of $\mathrm{N}$ relative to $\mathrm{P}$ was apparent in upper bay sediments (Fig. 7).

As discussed earlier, the increase in particulate $\mathrm{C}: \mathrm{N}$

Table 1. Estimates of the importance of SOD as an oxygen sink compared to total water-column respiration and benthic $\mathrm{NH}_{4}^{+}$flux as a phytoplankton nutrient source for 4 regions of Chesapeake Bay

\begin{tabular}{|c|c|c|c|c|c|c|c|}
\hline Location & Date & $\begin{array}{l}\text { Total } \\
\text { water column } \\
\text { respiration } \\
\left(\mathrm{g} \mathrm{O}_{2} \mathrm{~m}^{-2} \mathrm{~d}^{-1}\right)\end{array}$ & $\begin{array}{c}\text { Sediment } \\
\text { oxygen } \\
\text { demand, } \mathrm{SOD} \\
\left(\mathrm{g} \mathrm{O}_{2} \mathrm{~m}^{-2} \mathrm{~d}^{-1}\right)\end{array}$ & $\begin{array}{c}\text { SOD: } \\
\text { total } \\
\text { respiration } \\
(\%)\end{array}$ & $\begin{array}{l}\text { Phytoplankton } \\
\text { N-require- } \\
\text { ment }^{\mathrm{b}} \\
\left(\mathrm{mmol} \mathrm{m}^{-2} \mathrm{~d}^{-1}\right)\end{array}$ & $\begin{array}{l}\text { Benthic } \mathrm{NH}_{4}^{+} \\
\text {regene- } \\
\text { ration } \\
\left(\mathrm{mmol} \mathrm{m}^{-2} \mathrm{~d}^{-1}\right)\end{array}$ & $\begin{array}{l}\text { Benthic } \\
\text { regeneration: } \\
\text { phytoplankton } \\
\text { demand }^{\mathrm{c}}(\%)\end{array}$ \\
\hline \multirow[t]{2}{*}{ Upper Bay } & Aug & 9.9 & 1.6 & 16 & 12.2 & 3.3 & 27 \\
\hline & May & 4.9 & 2.1 & 43 & 6.2 & 1.3 & 21 \\
\hline \multirow[t]{2}{*}{ Mid-Bay } & Aug & 19.1 & 3.1 & 16 & 33.9 & 13.5 & 40 \\
\hline & May & 3.6 & 1.8 & 50 & 11.2 & 2.1 & 18 \\
\hline \multirow[t]{2}{*}{ Lower Bay } & Aug & 3.2 & 1.5 & 47 & 48.9 & 6.3 & 13 \\
\hline & May & 4.4 & 1.5 & 34 & - & 0.9 & - \\
\hline \multirow[t]{2}{*}{ Tributaries } & Aug & 10.1 & 2.2 & 22 & 38.9 & 10.2 & 26 \\
\hline & May & 5.6 & 2.3 & 41 & 11.8 & 1.5 & 13 \\
\hline \multicolumn{8}{|c|}{$\begin{array}{l}\text { a Calculated as sum of water-column respiration and SOD. Plankton respiration data are from Taft et al. (1980) and Boynton et } \\
\text { al. (1982) } \\
\text { b Average rates of phytoplankton production for August and May periods were estimated using long-term records ( } 3 \text { to } 7 \mathrm{yr} \text { ) } \\
\text { of Flemer (1970) and Mihursky et al. (1978) for upper and mid-bay areas. Rates for the lower bay were from Boynton et al } \\
\text { (1982) while tributary rates were taken from D'Elia et al. (1981) and Boynton et al. (1982). Phytoplankton nitrogen demand } \\
\text { was estimated by assuming a C: N ratio of } 6.2 \text { (atomic) } \\
\text { c Percent of calculated phytoplankton nitrogen demand supplied by benthic } \mathrm{NH}_{4}^{+} \text {flux }\end{array}$} \\
\hline
\end{tabular}


for St B1 at about $16 \mathrm{~cm}$ sediment (Fig. 7 a) is probably a relict of the major depositional event occurring in 1972 (Schubel \& Hirschberg 1977). The low particulate N:P ratio at that station, especially in the upper $10 \mathrm{~cm}$ (Fig. 7b), corresponds to the high dissolved N:P ratio in pore-waters, and this relation may represent scavenging of $\mathrm{P}$ by iron and manganese oxy-hydroxides in the

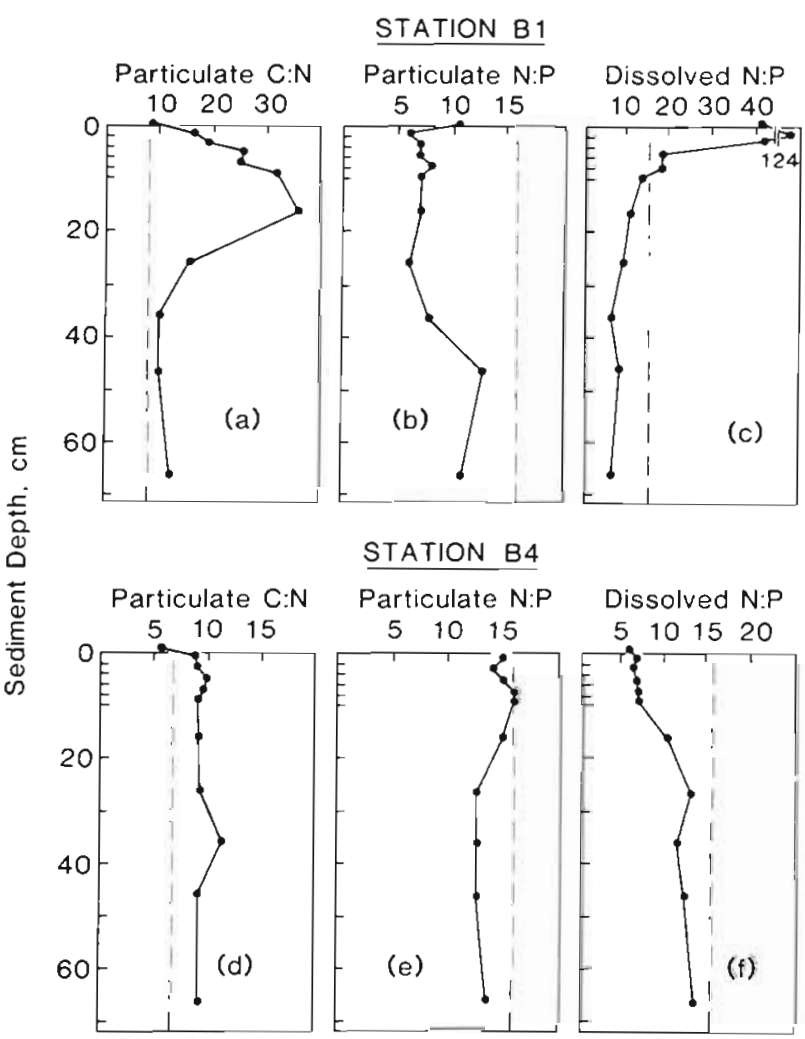

Fig. 7. Vertical composition ratios (atomic) of particulate and dissolved materials in sediments for August at St B1 and B4. Vertical lines indicate expected Redfield composition ratios

upper aerated sediments (e.g. Bricker \& Troup 1975, Callender 1982). At St B4 the particulate ratios, C:N and $\mathrm{N}: \mathrm{P}$, were remarkably constant with depth and differed only slightly from Redfield proportions (Fig. $7 \mathrm{~d}, \mathrm{e}$ ), indicating an absence of differential diagenic processing of these elements. The slight enrichment in particulate N:P and depletion of dissolved N:P in the upper $20 \mathrm{~cm}$ may represent the effects of denitrification in these sediments. The stoichiometric profiles for all mid and lower bay as well as tributary stations followed patterns similar to those for St B4. Thus these data suggest that the seasonally varying stochiometry of organic matter decomposition arises from annual patterns of denitrification and DIP precipitation-dissolution. Both of these processes are, in turn, affected by rates of organic matter deposition and sediment redox potential.

\section{Influence of sediment processes on estuarine waters}

The relative influence of sediment processes on overlying waters can be viewed in terms of watercolumn $\mathrm{O}_{2}$ and nutrient budgets. To evaluate the importance of SOD on oxygen conditions, we compared it with total community respiration (Rt), estimated as the sum of water column respiration plus SOD. Here SOD ranged from 13 to $67 \%$ of Rt (Table 1) and displayed no clear spatial or depth-related patterns. The mean contribution of SOD relative to Rt was higher in May $(48 \%)$ than August $(25 \%)$, largely attributable to strong seasonal differences in water column respiration rather than changes in SOD. These results are similar to those of Peterson (1979) who calculated that SOD represented about $50 \%$ of total community respiration in San Francisco Bay. In a previous study, we found that SOD accounted for 30 to $40 \%$ of Rt during the summer in the region of Chesapeake Bay near St B3 (Kemp \& Boynton 1980). These direct measurements of SOD are considerably higher than those calculated by Taft et al. (1980) for Chesapeake Bay, and our observations emphasize the potential importance of this pathway contributing to seasonal $\mathrm{O}_{2}$ depletion in mid Chesapeake Bay (Officer et al. 1984).

A second pathway of benthic-pelagic coupling which can be evaluated involves the release of nutrients from sediments to overlying waters. We estimated the potential influence of this process by comparing calculated phytoplankton demand for $\mathrm{NH}_{4}^{+}$to that supplied by sediment regeneration (Table 1). We have limited discussion to $\mathrm{NH}_{4}^{+}$because this appears to be the preferred form of nitrogen in most areas of the bay (McCarthy et al. 1975). Since we did not have direct measurements of phytoplankton nitrogen demand, this was estimated by combining Redfield composition ratios with phytoplankton productivity data. Given the considerable spatial and short-term (diel) variability associated with instantaneous measurements of nutrient uptake (Caperon et al. 1979, Kuenzler et al. 1979), the ratio approach may be more appropriate for calculating longer-term average rates. This method is also supported by the fact that $\mathrm{C}: \mathrm{N}$ ratios of suspended material largely approximated those expected by the Redfield model for phytoplankton (Fig. 5). In this analysis sediment fluxes of $\mathrm{NH}_{4}^{+}$ represented from $13-40 \%$ of calculated photosynthetic demand, and averaged 27 and $15 \%$ in August and May, respectively. There was a distinct spatial pattern, with sediment nutrient regeneration most important in mid-bay (where productivity was also greatest) and decreasing in both up-bay and down-bay directions. In addition, there was a distinct seasonal pattern wherein the percentage of nutrient demand supplied by the 
sediments was higher in the summer than spring, paralleling the trend in primary productivity.

Sediment regeneration of $\mathrm{NH}_{4}^{+}$at our stations exerted a substantial (although not dominant) influence on overall nutrient dynamics, with marked spatial and temporal patterns. Nixon et al. (1976), Boynton et al. (1980), Fisher et al. (1982) and others (e.g. Zeitzschel 1980) have shown that benthic regeneration may represent the major source of $\mathrm{NH}_{4}^{+}$in shallow coastal systems; however, the significance of this source seems to vary. Other authors have reported that water-column regeneration (zooplankton and bacterial excretion) can supply $100 \%$ or more of phytoplankton N-demand (e.g. Harrison 1978, Caperon et al. 1979, Hattori et al. 1980). In fact, Glibert (1982) found that about 70 to $90 \%$ of phytoplankton $N$-requirements were satisfied by water-column regeneration at 3 sites in Chesapeake Bay (located near our St B4, B5 and T1) in early June 1980. Thus, it appears that both pelagic and benthic N-regeneration are important in many coastal systems (including Chesapeake Bay) and that the total often exceeds phytoplankton demand. A logical next step in improving our understanding of benthic-pelagic couplings would involve contemporaneous measurements of both water column and benthic processes over appropriate spatial gradients and temporal intervals.

Acknowledgements. We are indebted to many individuals, including: K. Wood, C. Keefe, C. Osborne, K. Kaumeyer, M. Jenkins, E. Spalding, L. Lubbers, T. Jones and T. Farrell for help in sampling operations and laboratory analyses; Captains W. Keefe and D. Younger for conducting research vessel operations; C. D'Elia, J. Taft and M. Roman for helpful suggestions and reviews of an earlier version of the manuscript and E. Callander for collaboration in collection of sediment data.

This work was supported by grants from US Environmental Protection Agency (CR807637-01); Maryland Dept. Natural Resources, PPSP, No. P2-72-02(80); and the University of Maryland Computer Science Center

\section{LITERATURE CITED}

Alvarez-Borrego, S., Guthrie, D., Culberson, C. H., Park, P. K (1975). Test of Redfield's model for oxygen relationships using regression analysis. Limnol. Oceanogr. 20 (5): $795-805$

Aspila, I., Agemian, H., Chau, A. S. Y. (1976). A semi-automated method for the determination of inorganic, organic and total phosphate in sediments. Analyst 101: 187-197

Biggs, R. B. (1970). Sources and distribution of suspended sediment in nothern Chesapeake Bay. Mar. Geol. 9 : $187-201$

Boynton, W. R., Kemp, W. M., Osborne, C. G. (1980). Nutrient fluxes across the sediment water interface in the turbid zone of a coastal plain estuary. In: Kennedy, V. S. (ed.) Estuarine perspectives. Academic Press, New York, p. 93-109
Boynton, W. R., Kemp, W. M., Osborne, C. G., Kaumeyer, K. R., Jenkins, M. C. (1981). Influence of water circulation rate on in situ measurements of benthic community respiration. Mar. Biol. 65 : 185-190

Boynton, W. R., Kemp, W. M., Osborne, C. G., Spalding, E. Keefe, C. W., Wood, K. V. (1982). Estuarine community dynamics in relation to power plant operations. Univ. Md. Cntr. Environ. Estuar. Stud. Ref. No. 82-78 CBL

Bray, J. T., Bricker, O. P., Troup, B. N. (1973). Phosphate in interstitial waters of anoxic sediments: oxidation effects during sampling procedure. Science, N.Y. $180: 1362-1364$

Bricker, O. P., Troup, B. N. (1975). Sediment-water exchange in Chesapeake Bay. In: Cronin, L. E. (ed.) Estuarine research, Vol. 1. Chemistry, biology and the estuarine system. Academic Press, New York, p. 3-27

Brush, G. S., DeFries, R. S. (1981). Spatial distributions of pollen in surface sediments of the Potomac estuary. Limnol. Oceanogr. 26 (2) : 295-309

Callender, E. (1982). Benthic phosphorus regeneration in the Potomac River estuary. Hydrobiologia 92 : 431-446

Callender, E., Hammond, D. E. (1982). Nutrient exchange across the sediment-water interface in the Potomac River estuary. Estuar. coast. Shelf Sci. 15 : 395-413

Caperon, J., Schell, D., Hirota, J., Laws, E. (1979). Ammonium excretion rates in Kaneohe Bay, Hawaii, measured by a ${ }^{15} \mathrm{~N}$ isotope dilution technique. Mar. Biol. $54: 33-40$

D'Elia, C. F., Steudler, P. A., Corwin, N. (1977). Determination of total nitrogen in aqueous samples using persulfate digestion. Limnol. Oceanogr. 22:760-764

D'Elia, C. F., Boynton, W. ., Kemp, W.M., Wood, K. V., Keefe, C. W., Farrell, T., Tuttle, J. H. (1981). Benthic nutrient studies on the lower Patuxent River, Final Rept. to MD Dept. Nat. Res. UMCEES Ref. No. 81-190 CBL

D'Elia, C. F., Nelson, D. M., Boynton, W. R. (1983). Chesapeake Bay nutrient and plankton dynamics: III. The annual cycle of dissolved silicon. Geochim. cosmochim. Acta 47: 1945-1955

Elderfield, H., Luedtke, N., McCaffrey, R. J., Bender, $M$. (1981). Benthic flux studies in Narragansett Bay. Am. J. Sci. 281: 768-787

Environmental Protection Agency (EPA) (1979). Methods for chemical analysis of water and wastes. USEPA-600/4-79020. Environmental Monitoring and Support Laboratory, Cincinnati

Fisher, T. R., Carlson, P. R., Barber, R. T. (1982). Sediment nutrient regeneration in three North Carolina estuaries. Estuar. coast. mar. Sci. 14: 101-116

Flemer, D. A. (1970). Primary production in the Chesapeake Bay. Chesapeake Sci. 11: 117-129

Glibert, P. M. (1982). Regional studies of daily, seasonal and size-fraction variability in ammonium remineralization. Mar. Biol. 70: 209-222

Goldberg, E. D., Hodge, V., Koide, M., Griggin, J., Gamble, E., Bricker,O. P., Matisoff, G., Holdren, G. R., Jr., Braun, R. (1978). A pollution history of Chesapeake Bay. Geochim. cosmochim. Acta 42: 1413-1425

Hargrave, B. T., Taguchi, S. (1978). Origin of deposited material sedimented in a marine bay. J. Fish. Res. Bd Can. 35: $1604-1613$

Harrison, W. G. (1978). Experimental measurement of nitrogen remineralization in coastal waters. Limnol. Oceanogr. 23: $684-694$

Hattori, A., Koike, I., Ohtsu, M., Goering, J. J., Boisseau, D. (1980). Uptake and regeneration of nitrogen in controlled aquatic ecosystems and the effects of copper on these processes. Bull. mar. Sci. 30: 431-443

Hirschberg, D. J., Schubel, J. R. (1979). Recent geochemical 
history of flood deposits in the nothern Chesapeake Bay. Estuar. coast. mar. Sci. 9: 771-784

Jenkins, M. C. (1981). The measurement, occurrence, and importance of nitrification and denitrification in Chesapeake Bay sediments. M. Sc. thesis, University of Maryland, College Park

Jenkins, M. C., Kemp, W. M. (1984). The coupling of nitrification and denitrification in two estuarine sediments. Limnol. Oceanogr. 29 (3): 609-619

Kemp, W. M., Boynton, W. R. (1980). Influence of biological and physical factors on dissolved oxygen dynamics in an estuarine system: implications for measurement of community metabolism. Estuar. coast. mar. Sci. 11: 407-431

Kemp, W. M., Boynton, W. R. (1981). External and internal factors regulating metabolic rates of an estuarine benthic community. Oecologia 51: 19-27

Khalid, R. A., Patrick, W. H., Jr., Gambress, R. P. (1978). Effect of dissolved oxygen on chemical transformation of heavy metals, phosphorus and nitrogen in an estuarine sediment. Estuar. coast. mar. Sci. 5: 21-35

Klump, J. V., Martens, C. S. (1981). Biogeochemical cycling in an organic rich coastal marine basin. II. Nutrient sediment-water exchange processes. Geochim. cosmochim. Acta 45: 101-121

Koike, I., Hattori, A. (1978a). Denitrification and ammonia formation in anaerabic coastal sediments. Appl. environ Microbiol. 34: 278-282

Koike, I., Hattori, A. (1978b). Simultaneous determinations of nitrification and nitrate reduction in coastal sediments by a ${ }^{15} \mathrm{~N}$ dilution technique. Appl. environ. Microbiol. 35: $853-857$

Krom, M. D., Berner, R. A. (1980). The diffusion coefficients of sulfate, ammonium and phosphate ions in anoxic marine sediments. Limnol. Oceanogr. 25: 327-337

Kuenzler, E. J., Stanley, D. W., Koenings, J. P. (1979). Nutrient kinetics of phytoplankton in the Pamlico River, North Carolina. Univ. North Carolina Water Resour. Inst. Rep. 139

Martens, C. S., Goldharber, M. B. (1978). Early diagenesis in transitional sedimentary environments of the White Oak River estuary, North Carolina. Limnol. Oceanogr. 23 (3): $428-441$

Matisoff, G., Bricker, O. P., Holdren, G. R., Kaerk, P. (1975). Spatial and temporal variations in the interstitial water chemistry of Chesapeake Bay sediments. In: Church, T. M. (ed.) Marine chemistry in the coastal environment. ACS Symposium Series No. 18, Washington, DC, p. 343-363

Matson, E. A., Brinson, M. M., Cahoon, D. D., Davis, G. J. (1983). Biogeochemistry of the sediments of the Pamlico and Neuse River estuaries, North Carolina. Water Resources Res. Inst. Rep. No. 191, Raleigh, NC

McCarthy, J. J., Taylor, W. R., Taft, J. L. (1975). The dynamics of nitrogen and phosphorus cycling in the open waters of the Chesapeake Bay. In: Church, T. M. (ed.) Marine chemistry in the coastal environment. ACS Symposium Series No. 18, Washington, DC, p. 664-681

Mihursky, J. A., Heinle, D. R., Boynton, W. R. (1978). Ecological effects of nuclear steam electric station operations on estuarine systems. Univ. Md. Cntr. Environ. Estuar. Stud. Ref. No. 77-28 CBL

Müller, P. J. (1977). C/N ratios in pacific deep-sea sediments: effect of inorganic ammonium and organic nitrogen compounds sorbed by clays. Geochim. cosmochim. Acta 41: 765-776

Nishio, T., Koike, I., Hattori, A. (1982). Denitrification, nitrate reduction, and oxygen consumption in coastal and estuarine sediments. Appl, environ. Microbiol. 43 648-653

Nixon, S. W. Kelly, J. R., Oviatt, C. A., Hale, S. S. (1976) Nitrogen regeneration and the metabolism of coastal marine bottom communities. In: Anderson, J. M., MacFadden, A. (ed.) The role of terrestrial and aquatic organisms in decomposition processes. The 17 th Symposium of the British Ecological Society. Blackwell, Oxford, p. 269-283

Nixon, S. W., Kelly, J. R., Furnas, B. N., Oviat, C. A., Hale, S. S. (1980). Phosphorus regeneration and the metabolism of coastal marine bottom communities. In: Tenore, K.R. Coull, B. C. (ed.) Marine benthic dynamics. University of South Carolina Press, Columbia, S.C., p. 219-242

Nixon, S. W. (1981). Remineralization and nutrient cycling in coastal marine ecosystem. In: Neilson, B. J., Cronin, L. E. (ed.) Estuaries and nutrients. Humana Press, Clifton, N. J., p. $111-138$

Officer, C. B., Biggs, R. B., Taft, J. L., Cronin, L. E., Tyler, M. A., Boynton, W. R. (1984). Chesapeake Bay anoxia: origin, development, and significance. Science, N. Y. 223: 22-27

Peterson, D. H. (1979). Sources and sinks of biologically reactive oxygen, carbon, nitrogen, and silica in northern San Francisco Bay. In: Conomos, T. J. (ed.) San Francisco Bay: the urbanized estuary. AAAS, Allen Press, Lawrence, Kansas, p. 175-194

Pritchard, D. W. (1952). Salinity distribution and circulation in the Chesapeake Bay estuarine system. J. mar. Res. 11 (2): 106-123

Pritchard, D. W. (1967). Observations of circulation in coastal plain estuaries. In: Lauff, G. H. (ed.) Estuaries. AAAS Publ. 83, Washington, DC, p. 37-44

Redfield, A. C. (1934). On the proportions of organic derivatives in seawater and their relation to the composition of plankton. In: James Johnstone Memorial Volume. University Press, Liverpool, p. 176-192

Reeburgh, W. S. (1967). An improved interstitial water sampler. Limnol. Oceanogr. 12: 163-165

Schubel, J. R., Hirschberg, D. J. (1977). $\mathrm{Pb}^{210}$-determined sedimentation rate, and accumulation of metals in sediments at a station in Chesapeake Bay. Chesapeake Sci. 18 (4): $379-382$

Seitz, R. C. (1971). Temperature and salinity distributions in vertical sections along the longitudinal axis and across the entrance of the Chesapeake (April 1968 to March 1969). Chesapeake Bay Inst., Graphical Summary Rept. No. 5, The Johns Hopkins University

Seitzinger, S., Nixon, S., Pilson, E. M. Q., Burke, S. (1980). Denitrification and $\mathrm{N}_{2} \mathrm{O}$ production in nearshore marine sediments. Geochim. cosmochim. Acta 44: 1853-1860

Seitzinger, S. P., Nixon, S. W., Pilson, E. M. Q. (1984). Denitrification and nitrous oxide production in a coastal marine ecosystem. Limnol. Oceanogr. 29 (1): 73-83

Sharp, J. H., Culberson, C. H., Church, T. M. (1982). The chemistry of the Delaware Estuary. General considerations. Limnol. Oceanogr. 27: 1015-1028

Smetacek, V., Brockel, K. V., Zeitzschel, B., Zenk, W. (1978). Sedimentation of particulate matter during a phytoplankton spring bloom in relation to the hydrographic regime. Mar. Biol. 47: 211-226

Smith, K. L., Jr. (1973). Respiration of a sublittoral community. Ecology 54: 1065-1075

Stephens, K., Sheldon, R. W., Parsons, T. R. (1967). Seasonal variations in the availability of food for benthos in a coastal environment. Ecology 48(5): 852-855

Strickland. J. D. H., Parsons, T. R. (1968). A practical handbook of sea-water analysis. Fish. Res. Bd Can. Bull. No. 167 
Taft, J. L., Taylor, W. R. (1976). Phosphorus distribution in the Chesapeake Bay. Chesapeake Sci. 17 (2): 67-73

Taft, J. L., Taylor, W. R., Hartwig, E. O., Loftus, R. (1980). Seasonal oxygen depletion in Chesapeake Bay. Estuaries 3: $242-247$

Walsh, J. J., Premuzic, E. T., Whitledge, T. E. (1981). Fate of nutrient enrichment on continental shelves as indicated by the $\mathrm{C} / \mathrm{N}$ content of bottom sediments. In: Nihoul, J. C. J. (ed.) Ecohydrodynamics. Elsevier, Amsterdam, p. 13-49 Whaley, R. D., Carpenter, J. H., Baker, R. L. (1966). Nutrient data summary 1964, 1965, 1966; upper Chesapeake Bay (Smith Point to Turkey Point), Potomac South, Severn, Magothy, Back, Chester and Miles Rivers; and Eastern Bay. Chesapeake Bay Inst. Spec. Rept. 12, The Johns Hopkins Univ., Baltimore

Zeitzschel, B. (1980). Sediment water interactions in nutrient dynamics. In: Tenore, K. R., Coull, B. C. (ed.) Marine benthic dynamics. University of South Carolina Press, Columbia, S.C., p. 195-218.

This paper was presented by Professor S. W. Nixon; it was accepted for printing on December 22, 1984 